Consumption, Media and the Global South 
This page intentionally left blank 


\section{Consumption, Media and the Global South}

\section{Aspiration Contested}

Mehita Iqani

University of the Witwatersrand, South Africa 


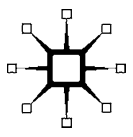

(C) Mehita Iqani 2016

Softcover reprint of the hardcover 1st edition 2016 978-1-137-39012-7

All rights reserved. No reproduction, copy or transmission of this publication may be made without written permission.

No portion of this publication may be reproduced, copied or transmitted save with written permission or in accordance with the provisions of the Copyright, Designs and Patents Act 1988, or under the terms of any licence permitting limited copying issued by the Copyright Licensing Agency, Saffron House, 6-10 Kirby Street, London EC1N 8TS.

Any person who does any unauthorized act in relation to this publication may be liable to criminal prosecution and civil claims for damages.

The author has asserted her right to be identified as the author of this work in accordance with the Copyright, Designs and Patents Act 1988.

First published 2016 by

PALGRAVE MACMILLAN

Palgrave Macmillan in the UK is an imprint of Macmillan Publishers Limited, registered in England, company number 785998, of Houndmills, Basingstoke, Hampshire RG21 6XS.

Palgrave Macmillan in the US is a division of St Martin's Press LLC, 175 Fifth Avenue, New York, NY 10010.

Palgrave Macmillan is the global academic imprint of the above companies and has companies and representatives throughout the world.

Palgrave ${ }^{\circledR}$ and Macmillan ${ }^{\circledR}$ are registered trademarks in the United States, the United Kingdom, Europe and other countries.

\section{ISBN 978-1-349-55701-1ＩSBN 978-1-137-39013-4 (eBook) \\ DOI 10.1057/9781137390134}

This book is printed on paper suitable for recycling and made from fully managed and sustained forest sources. Logging, pulping and manufacturing processes are expected to conform to the environmental regulations of the country of origin.

A catalogue record for this book is available from the British Library.

Library of Congress Cataloging-in-Publication Data

Iqani, Mehita, author.

Consumption, media and the Gobal South : aspiration

contested / Mehita Iqani.

pages $\mathrm{cm}$

1. Consumption (Economics)—Social aspects—Developing countries.

2. Mass media—Social aspects—Developing countries.

3. Capitalism and mass media-Developing countries. I. Title.

HC59.72.C6173 2015

$338.4^{\prime} 7091724-d c 23$ 
For my parents, Anne and Bijan 
This page intentionally left blank 


\section{Contents}

List of Tables $\quad$ xi

Acknowledgements xii

List of Acronyms xiv

1 Introduction: The Mediation of Global South

Consumption 1

The global south: Experimental term, analytical

opportunity 2

Transnational comparative case studies: Challenges and prospects 9

Chapter outline $\quad 13$

The materiality of mediated consumption 16

2 Globalization, Consumption and Power: Why Media Matter 18

Media and global culture 19

Theorizing mediated globalization $\quad 19$

Media discourse and power $\quad 22$

Consumer culture and globalization 23

The legacy of colonialism 23

The political economy of globalized consumption 29

Moralizing southern consumption 32

The developmentalist ethic: Can consumption save the south?

Inequality and avarice: Consumption as globalized exploitation 38

Studying the mediation of southern consumption:

A conceptual matrix

Consumption as power: Manipulation and empowerment reloaded

Consumption as aspiration: Poverty and wealth depolarized

Consumption as communication: Semiotic doubling in distinction and mediation

Summing up: Consumption, inequality and aspiration 


\section{Slum Tourism and the Consumption of Poverty in} TripAdvisor Reviews: The Cases of Langa, Dharavi and Santa Marta

Slum tourism: Globalized gazing and the mediation of poverty

Global mobility and the exploitative gaze: Who looks and who is looked at?

Ethical witnessing? Politics, development and social realism in slum tours

The mediation of slum tourism: Glamorous or realist aesthetics?

Case studies: Dharavi, Santa Marta and Langa tours on

TripAdvisor.com

Slum tours reviewed: Discourses on value, morality and

learning

"Highlight": Value for money and the commoditized experience

"Humbling": Material poverty, spiritual wealth and questions of perspective

"Eye-opening": Dealing with reality and the geopolitics of the class encounter

Slum tours: Commoditized, moralized and mediated

(a conclusion)

4 New Yuppies? Documentary Film Representations of Middle-Class Consumer Lifestyles in China and South Africa

Global south "yuppies"? Middle-class culture and capital

The middle class: Contested, constructed, relational

Salaried and spending: Economic capital, income and agency

Taste and mobility: Cultural capital, globalization and identity

"Yuppies" on film: Documenting social mobility in China and South Africa

The dream, success and morality: The representation of

Chinese and black South African yuppie subjectivities

Prosperity and time: Narratives of the dream

On the symbolism of the luxury car: Spending and success 
Living it up, playing it down: Deserving and democratizing wealth

Mediating the yuppie: Neoliberal culture and southern upward mobility

5 Allegations of Consumption: Wealth and Luxury in News Reports of Corruption in South Africa and India

Corruption, society and the media: Interdisciplinary debates

Abusing power: Defining corruption and its consequences Stereotypes of instability? Framing global south corruption

Exposing corruption, demanding accountability: The role of the media

Consumption or corruption in the spotlight? Four cases

Winnie and the diamond deal

Yengeni and the luxury Mercedes-Benz $4 \times 4$

Mayawati and the rupee garland

144

Jagan and the lavish mansion

Theorizing corrupt consumption: Excess, aspiration and power

Taking it too far? The symbolism of excess

Signifying aspiration: Populism and pleasure

Agency or betrayal? The power of expenditure

Corrupt consumers or consuming corruption? Concluding thoughts

6 Celebrity Skin: Race, Gender and the Politics of Feminine Beauty in Celebrity Selfies

Celebrities in/and the global south: Development and desire

Celebrity aid, humanitarianism and development

"Exotic" stars: Southern celebrities on the western stage

The aesthetics of success: Race and beauty in the global south

Case studies: Black stars' celebrity selfies

Black/bleached beauties: The aesthetics and politics of individualism, consumption and sexiness

Me, myself and I: Selfies, intimacy and the ethic of individualism 
Consumer queens: Fashion, styling and the world of feminine goods

The sexiness queue? Post-feminist aesthetics and classed desirability

Empowered role models? Sexy southern stars, race and the politics of post-femininity

7 Contesting Aspiration: Equality, Empowerment and Media Narratives about Consumption

Consumption as communication: Relinking consumer culture and media

The politics of aspiration: Negotiating between the dream and reality

Consumption as power: Getting it, exercising it, resisting it 208

Looking ahead: New avenues for researching the mediation of global south consumption 


\section{Tables}

4.1 Documentaries analysed for Chapter 4

100 


\section{Acknowledgements}

Writing this book has been a most collaborative and a most solitary experience. The hundreds of hours I've spent alone, disciplining myself to just write, have been in counterpoint with the many formative, stimulating and indispensable conversations about it that I've had with friends, colleagues and friends of friends. I owe thanks to so many, and have endeavoured to remember everyone who helped me along the way, no matter how small they may have seen their contributions to be. In particular, I am hugely grateful to colleagues who took time out of their busy schedules to read and comment on draft chapters, sharing their valuable thoughts and suggestions: Nicky Falkof, Dina Ligaga, Cobus van Staden, Glenda Daniels, Isabel Hofmeyr, Tommaso Milani, Ufuoma Akpojivi and Charne Lavery.

To those who helped me think through case studies or access archival media material, suggested a particular empirical route, listened to me present on work in progress, had exploratory chats over coffee, explained something about India, Brazil or China, gave me pep talks, encouraged me, or suggested things to read, thank you: Innocentia Mhlambi, Hennie van Vuuren, Amanda Gilbertson, Sarah Chiumbu, Nic Dawes, Ranjana Das, Shilpa Phadke, Dilip Menon, Srila Roy, Marcia Tondato, Gisela Castro, Bridget Kenny, Zhiyan (Maggie) Wu, Michael Griffiths, Pamila Gupta, Gilles Baro and Gen-Nam Chow. My deep thanks also go to my "transnational mentors", Rosalind Gill, Lilie Chouliaraki and Jonathan Schroeder, who provided me with extremely helpful feedback at the conceptualization stage and who I know will always be at the other end of the email when I need their advice. I'd also like to thank colleagues who participated in the May 2014 Global South Workshop in the Wits-Michigan 'Sugarman' network for helping me to shape my contribution to that topic. My thanks also go to Simon Wood and Saskia Vredefeld for giving me copies of their films, Foreunners and Black Diamonds, respectively, as well as to archivists at the Times of India and the Mail \& Guardian, who helped me access historical material.

I am indebted to the collegiate and intellectually stimulating work of the Critical Research in Consumer Culture network - the reading groups, seminars, writing retreats, workshops and conferences we've organized and attended together have shaped my thinking in the past few years. I am also indebted to the marvellous research environment 
created by the University of the Witwatersrand. In my four years of service there, I have been awarded a number of grants which allowed me to do all the empirical work for this book and balance my teaching responsibilities with the intensive effort required to do this research and writing. I am deeply thankful for the resources provided by the National Research Foundation's Thuthuka Grant (2012-2014), the University of the Witwatersrand's Friedel Sellschop Award (2014-2016), the Faculty of Humanities Research Promotion Grant (2014), the SPARC fund (2013), the Wits Carnegie Young Scholars Grant (2012) and the AW Mellon Young Researcher Grant administered by the Wits Faculty of Humanities (2012).

This book would not be this book were it not for my students, who have taught me so much and inspired me in so many ways. In particular, I am grateful to Katlego Disemelo and Simphiwe Rens for research assistance at various stages in the work that has led to this volume. I also owe a big shout-out to the brilliant Critical Media Analysis class of the honours 2014 cohort, who enthused me with their passionate engagement with research into crucial contemporary questions in media and cultural studies. In particular, Chapter 6 is my response to their provocations to think more about globalized narratives of feminine beauty, race, shade-ism and celebrity.

I would not have been able to achieve anything careerwise without the support and care of everyone in my personal life. To my family, all the in-laws and all my friends, thanks for asking how the book was going and listening when I answered, for being there to distract me when I needed it, and for understanding when I had to hide away and work. To Davey, you're my number one, my favourite person, my best teammate: thank you again and always for everything. 


\section{Acronyms}

$\begin{array}{ll}\text { AAP } & \text { Aam Aadmi Party } \\ \text { ANC } & \text { African National Congress } \\ \text { AP } & \text { Andhra Pradesh } \\ \text { BBC } & \text { British Broadcasting Corporation } \\ \text { BEE } & \text { Black Economic Empowerment } \\ \text { BMW } & \text { Bavarian Motor Works } \\ \text { BRICS } & \text { Brazil Russia India China South Africa } \\ \text { BSP } & \text { Bahujan Samaj Party } \\ \text { CAPP } & \text { Co-ordinated Anti Poverty Programme } \\ \text { CBI } & \text { Central Bureau of Investigation } \\ \text { CPI } & \text { Corruption Perceptions Index } \\ \text { FHM } & \text { For Him Magazine } \\ \text { FIR } & \text { First Information Report } \\ \text { GDP } & \text { Gross Domestic Product } \\ \text { IMF } & \text { International Monetary Fund } \\ \text { I-T } & \text { Income Tax } \\ \text { MP } & \text { Member of Parliament } \\ \text { MTV } & \text { Music Television } \\ \text { NAM } & \text { Non-Aligned Movement } \\ \text { NGO } & \text { Non-Governmental Organization } \\ \text { NWICO } & \text { New World Information and } \\ \text { SUV } & \text { Communications Order } \\ \text { TI } & \text { Sports Utility Vehicle } \\ \text { UK } & \text { Transparency International } \\ \text { UP } & \text { United Kingdom } \\ \text { US } & \text { Uttar Pradesh } \\ \text { YSR (Congress Party) } & \text { United States } \\ & \text { Yuvajana, Shramika, Rythu Congress Party } \\ & \end{array}$

